\title{
Mineralization in Granitic intrusive Of Kanigiri area in Andhra Pradesh: A root cause for Fluoride Dominance in Ground Water - A Case Study
}

\author{
M.R.S.Sampath Kumar \\ Department of Geo-Physics \\ Andhra University \\ Visakhapatnam-530046 \\ India
}

\author{
G. Swathi \\ Department of Geo-Physics \\ Andhra University, \\ Visakhapatnam-530046 \\ India
}

\begin{abstract}
:
The Kanigiri-Podili tract of Nellore and Prakasam districts of Andhra Pradesh were known for abnormal fluoride content and interesting mineralogy. Kanigiri town in Topo-Sheet No.57M/11 of Survey of India is surrounded by granitic intrusive. Alkaline magmatism was widespread in the granulite terrain of southern peninsular India during the proterozoic. The forty seven alkaline to mildly alkaline plutons and carbonatite complexes of varying dimensions and shapes cover a total area of approximately 450 sq.Km and define an alkaline belt along the east coast of India. The rocks of the area are holocrystalline-hypidiomorphic texture and composed mainly of orthoclase, microcline, albite, and zircon as chief accessory minerals fluorite, topaz, apatite are the other accessosories as served in the rock.

The present work focuses on the origin of fluoride in waters around Kanigiri area. In general the dissociation of granitic rocks exposed to prolonged sun and runoff results apatites in to water. This in turn enriches the Fluoride content. But here the mechanism is different. Endemic fluorosis is prevalent amongst the habitants of the high fluorine content in ground water. Streaks and Lenses of fluorite are common feathers in these granites. The earlier workers attributed the origin to the replacement of the existing rocks by "granitic juice" having a high volatile content. Small patches of Sodalite-Cancrinite-Fluorite-Nepheline bearing syenites hosted within the fluorite bearing grey granite near Podili. Detailed water sampling around Kanigiri and Podili has been made. They are analyzed to their complete major-ion analysis.
\end{abstract}

Keywords: fluoride enrichment, ground water, kanigiri, granite

\section{INTRODUCTION}

Groundwater chemistry is largely a function of the mineral composition of the aquifer through which it flows. The hydro chemical processes and hydro geochemistry of the groundwater vary spatially and temporally, depending on the geology and chemical characteristics of th aquifer. Hydro geochemical processes such as dissolution, precipitation, ion exchange processes and the residence time along the flow path control the chemical composition of groundwater.

In recent years, monitoring of Fluoride (F-) concentrations in the groundwater has become a great interest to the scientific and research community as this problem is universal. According to the Bureau of Indian Standard (BIS) the maximum tolerable limit of fluoride in Groundwater (GW) is $1.5 \mathrm{ppm}$.

\section{MATERIALS AND METHODS}

\subsection{Geology}

Prakasam district is surrounded by granitic intrusives. Alkaline magmatism was widespread in the granulite terrain of southern peninsular India during the Proterozoic. The forty seven alkaline to mildly alkaline plutons and carbonatite complexes of varying dimensions and shapes cover a total area of approximately $450 \mathrm{sq} . \mathrm{Km}$ and define an alkaline belt along the east coast of India. The rocks of the area are holocrystalline- hypidiomorphic texture and composed mainly of orthoclase, microcline, albite, and zircon as chief accessory minerals fluorite, topaz, and apatite are the other accessosories as served in the rock. The district is underlain by hard rock's $80 \%$ followed by alluvium $19 \%$ and soft rocks $1 \%$. Geological formations in the study area are covered with pink colored granite rock with red, black cotton and clay soils. The major water source of irrigation in district is Nagarjuna Sagar, Right Bank Canal and Gundlakamma River.

\subsection{Regional geology of the Study area}

The eastern margin of Cuddapah basin, a number of granitic bodies of mesoproterozoic age occur intermittently over a stretch of about $300 \mathrm{Km}$ from Vinukonda in the north to SriKalahasthi in the south. Notable among them are the Vinukonda granite, Darsi granite, Podili granite and Anumonakonda granite.Available trace element data along with the presence of fluorite in all these granites indicate that these granites have crystallized from the partial melting of dehydrated lower continental crust (Sarvothaman and Sesha Sai2010).

The Kanigiri pluton which is located between latitudes The Kanigiri is located between latitude $15^{0} 24^{1} 30^{11} \mathrm{~N}$ to $15^{0} 24^{1} 35^{11} \mathrm{~N}$ and longitudes $79^{0} 30^{1} 00^{11} \mathrm{E}$ to $79^{0} 30^{1} 06^{11} \mathrm{E}$ and is about $86 \mathrm{~km}$ WSW of Ongole, 
Prakasam district, Andhra Pradesh.Fig1 showing the location of the area. The Kanigiri pluton is elliptical, with NE-SW trending longer axis.It is intrusive into the Dharwar schists of the Nellore- Khammam schist Belt(NSB), and has been dated at $995 \mathrm{Ma}$ (Gupta et al 1984).Structural, petrological and petrochemical investigations suggest that the origin of the columbitebearing granite near Kanigiri, is due to the alteration of the original metasediments by injection of fluids rich in volatiles. The increase in the columbite content in the derived soils adjacent to the Mekeru River suggests that the Mekeru fault served as a conduit for their influx.

The study area covers Kanigiri mandel. Fig1 showing the location of the area.Water sampling was carried out at random covering at least one sample in a square kilometer area. Wherever wells and ponds exist in the study area, samples were collected. The drinking water from bore wells were extracted using hand pumps and well water. Samples were collected in clean and sterile one-litre polythene cans and stored in an icebox. Analysis was carried out for $\mathrm{pH}$, electrical conductivity (EC), total dissolved solids(TDS), total hardness (TH), total alkalinity (TA), chlorides (Cl-), sulfates ( $\left.\mathrm{SO}^{2-}\right)$, nitrates (NO3-) and fluorides (F-). The analysis for physico-chemical parameters and fluoride in ground and surface water samples was carried out according to the procedure outlined in standard methods. Fluoride (F-) was determined by SPANDS reagent method.

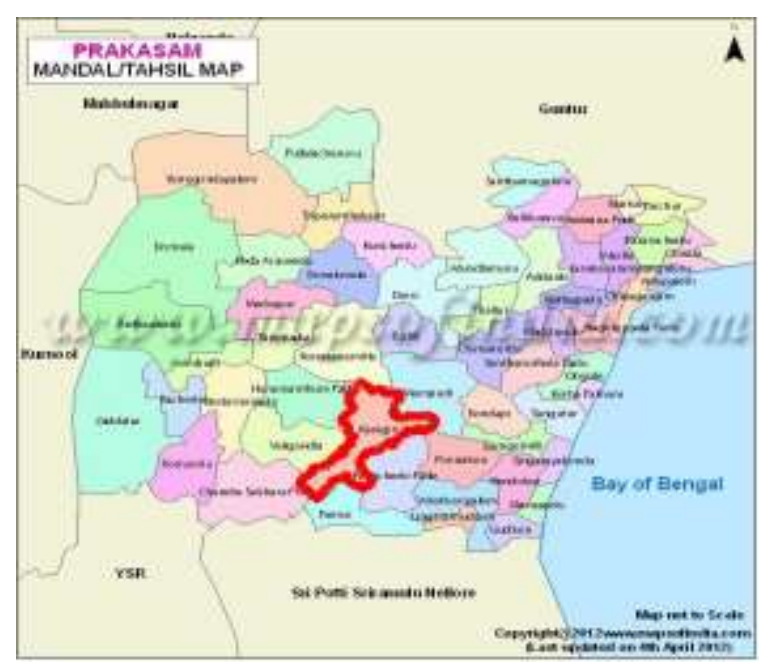

Fig1: Location map

$$
\bullet
$$

\section{RESULTS AND DISCUSSIONS}

\subsection{Geochemistry of Fluorine}

Fluorine, the lightest of the halogen elements, belongs to group 17 of the periodic table along with $\mathrm{F}, \mathrm{Cl}$, $\mathrm{Br}$ and I, and is one of most reactive of all elements.

It is known that fluorine is an element widely distributed in ore deposits and in accessory minerals in igneous rocks. As a mineralizer fluorine accompanies a large number of metals and it is this property fluorine that makes it a useful indicator in mineral exploration.
Fluorine occurs in many common rock forming minerals, including fluorite $\mathrm{CaF}_{2}$, which occurs in both igneous and sedimentary rocks, apatite $\mathrm{Ca}_{5}\left[\mathrm{po}_{4}\right]_{3}(\mathrm{Cl}, \mathrm{F}, \mathrm{OH})$, topaz $\mathrm{Al}_{2} \mathrm{~F}_{2}$ [SiO4], simple halides such as carobbite KF, silicates such as muscovite $\mathrm{KAl} 2(\mathrm{OH}, \mathrm{F}) 2[\mathrm{AlSi3O} 10]$ and a range of amphibole and mica minerals. Substitution of the F-ion for the isoelectronic hydroxyl $\mathrm{OH}-$ ion is commonplace, because of the similarity in ionic radii, although substitution will not occur $\mathrm{f}$ the $\mathrm{OH}$ - ion is acting as a donor in hydrogen bonding.(Wedephol,1978). Fig 2 illustrates the geochemical mobility of fluorine with respect to the other elements such as $\mathrm{As}, \mathrm{Ag}, \mathrm{U}, \mathrm{Cu}$ and Th are in the same range of geochemical mobility as shown by F. The average fluorine contents for granite ( $800 \mathrm{ppm}$ ) have limited value as contents range from tens of ppm to several percent and vary greately within and between different granite types. Fluorine may be concentrated or released by both alkaline and calc- alkaline series.

Extensive research has been carried out on the fluoride- hydroxyl exchange in geological material (Gillberg,1964;Stormer and Carmichael,1971; Ekstrom,1972; Munoz and Ludington,1974).The presence of higher concentrations of fluoride in areas of fluorinerich rocks is therefore explained on the basis of $\mathrm{F}^{-}=\mathrm{OH}^{-}$ interchange between minerals and water. This phenomenon enhances the detection of fluoride anomalies in water in mineralized terrains.



Fig2: showing relative geochemical mobility of Fluorine(after Dissanayake,1986).

\subsection{Hydrochemistry of fluorine}

Fig 3 shows the distribution of fluoride in ground water of Kanigiri. The obtained fluoride concentrations levels are showing in fig3 corresponding to each water sample of Kanigiri mandel. It is very clear that the highest concentrations of fluoride in the groundwater is recorded upto $14 \mathrm{ppm}$. 




Fig3: Fluoride distribution in groundwater

\section{CONCLUSION}

The boundary of Kanigiri is associated with plutons is a mineralized belt as evidenced by the discovery of many mineralisations along this granite. Recently people from AMD(Atomic Mineral Division), Hyderabad reported bastnaesite and hydroxyl bastnaesite(lanthum cerium fluoro- carbonate) from the kanigiri granite.Rare metal and rare earth bearing minerals identifies by X-ray diffraction(XRD)studies in Kanigiri granite are bastnaesite

\section{REFERENCES}

[1] Sarvothaman,H. and Sesha Sai,V.V.(2010) Global correlations of A-type granites and releated rocks, their mineralization and significance in lithospheric evolution.IGCP-510,pp.2-14.

[2] Gupta,J.N., Pandey,B.K., Chabria,T., Banerjee,D.C. and Jayaram,K.M.V(1984)Rb-Sr geochronological studies on the granites of Vinukonda and Kanigiri,Prakasam district, Andhra Pradesh, India.Pecambrian Res.,v.26,pp. 105 - 109.

[3] Hand book of Geochemistry Wedephol(1978)

[4] Gillberg,M., (1964) Halogens and hydroxyl contents of micas and amphiboles in Swedish granitic rocks Geochim.Cosmochim. Acta, 28 : 495-516. and hydroxyl bastnaesite, besides columbite-tantalite, monazite, fergusonite, thorite and euxenite.

The hydrochemistry of fluorine in the region shows a marked increase of fluoride in the ground water at the mineralized belt. It is postulated that the boundary is a deep-seated rift or miniplate boundary along which there was considerable exhalation of fluorine. This process would in all probability have been a result of granite magmatism associated with continental collision. Fluorine appears to have acted as a mineralizes for many metals including $\mathrm{Nb}, \mathrm{Ta}, \mathrm{Sn}, \mathrm{U} \mathrm{Th}$, and Rbas shown by the enrichment of these minerals in the Kanigiri Pluton.

Controls on the distribution of water qualities in the study area reflect water-rock interactions (affecting geochemistry); As groundwater flows through the strata of different mineralogical composition, the water composition undergoes adjustments caused by imposition of new mineralogically controlled thermodynamic constraints. The ground water existing in the Prakasam District of Andhra Pradesh State in South India is significantly affected by the excess concentrations of fluoride. The results revealed this alarming concentration of the fluoride in the study area of Prakasam District. The excess fluoride concentration in the study area may be attributed to the geological formation of that particular area and rapid ground water depletion. The water in the study area is not suitable for domestic consumption without prior treatment.

[5] Stormer.J.C. and Carmichael, I.S.E., (1971) Fluorinehydroxyl exchange in apatite and biotite: a potential igneous geothermometer. Contrib Mineral. Petrol.,31: 121-131.

[6] Ekstrom, T.K., (1972) The distribution of fluorine among some coexisting minerals. Contrib. Mineral Petrol., 34: 192-200.

[7] Munoz and Ludington., (1974) Fluoride - hydroxyl exchange in biotite Am. J. Sci., 274 : 396-413.

[8] Banerjee,D.C., Maithani,P.B., Ranganth,N. and Jayaram,K.M.V.(1983) Rare metal mineralization in granite rocks of the Kanigiri area in the Prakasam district,Andhrapradesh,India.Chemical geol.,v.39,pp.319-334

[9] G.Nagendra Babu,M.Sai Baba, Mary K.Kumar, Yamuna Singh(2013) Bastnaesite from Kanigiri granite, Prakasam district, Andhra Pradesh, Journal Geological Society of India, Vol.81, April 2013, pp, 447-450. 